\title{
Determinants of Subcontracting in Lao Garment Industry
}

\author{
Xayphone KONGMANILA \\ National University of Laos \\ E-Mail: kxayphone@gmail.com \\ Yoshi TAKAHASHI \\ Hiroshima University \\ E-Mail: yoshit@hiroshima-u.ac.jp
}

\begin{abstract}
Subcontracting firms play an important role in industrial development. One of the main reasons is that large firms subcontract small and medium-sized enterprises and by doing so, large firms can enjoy the advantage of lower wage of small firms (traditional approach) and/or they can enjoy the lower transaction cost from inter-firm cooperation in terms of technology, production and marketing (modern approach). This study aims at investigating the determinants of 42 subcontractors' behaviors in Lao garment industry. We utilize probit model in analyzing data from the field survey. The results of analysis follow modern subcontracting approach. Traditional subcontracting relation that has been simplified as the relationship between high wage firms employing male workers and low wage firms employing female workers is not important factor in explaining subcontracting behaviors of Lao garment industry. Rather, modern subcontracting relation approach matters much more in this industry.
\end{abstract}

Keywords: Subcontracting, Garment Industry, Probit Model, Lao PDR

\section{INTRODUCTION}

Subcontracting markets have grown at a greater rate than the industrial sector taken in it entirety for past 30 years (UNIDO, 2003). Therefore, subcontracting has been a dominant research topic in the literature of both developed and developing countries. Scholars in the field of economic development have conducted research on subcontracting and derived implication to policy makers (Watanebe, 1971; Spiegel, 1993; Labrianidis, 1995; Ceglie and Dini, 1999; Kimura, 2002; Rama and Calatrava, 2002; Wattanapruttipaisan, 2002; Taymaz and Kilicaslan, 2005; Rosés, 2005; 
Andrabe, et al. 2006; Ypeij, 1998; Burki and Terrell, 1998; Unni, et al., 1999).

Most of these studies mainly focus on the behaviors of both contractors (manufacturing firms or subcontract offering firms) and subcontractors (subcontracting firms or subcontract receiving firms). Some studies have explained the factors that determine subcontracting relationship (Kimura, 2002; Taymaz and Kilicaslan, 2005). Their results seem to vary from country to country and from industry to industry. The main concentrations of prior researches seem to shift from traditional theories to modern theories (networking or clustering). This phenomenon has changed from Watanabe (1971) and Berger and Piore (1984) to Kimura (2002), Hayashi (2002) and Taymaz and Kilicaslan (2005).

In the case of Lao garment industry, recent research confirmed that inter-firm cooperation among manufacturing firms and subcontracting firms which is one type of subcontracting relation is the most crucial factors that improve firm performance (Takahashi and Xayphone, 2008). Therefore, this study aims at answering this research question: what factors determine subcontracting behaviors in Lao garment industry? The rest of this paper is organized as follows. Next section provides the overview of Lao garment industry and subcontracting, followed by theories in analyzing subcontracting, literature review and hypotheses, methods, results, discussion and the last section is conclusion.

\section{THE LAO GARMENT INDUSTRY AND SUBCONTRACTING}

Lao garment industry has been developed under a new government's reform policy known as the New Economic Mechanism (NEM). This policy was first developed in 1986. It aims at transforming the economy from centrally planned to market-oriented system. The Lao garment industry started in 1990 with only two factories. It expanded to 57 export-oriented companies and 43 subcontracting companies in 2004 (ALGI, 2006). The garment industry as a whole creates about 30,000 jobs (Sakurai and Ogawa, 2006) and produces US\$100 million goods for export annually (Boutsivongsak et al., 2002). The main markets of Lao garment products are EU, USA, Japan and other ASEAN members.

During 1998 to 2002, Lao garment exports accounted for between 30 and 40 percent of total merchandise exports. Apart from electricity and mining sectors, Lao garment industry is the highest export revenue generator (Bounthavy et al., 2007). In year 2003-2004, it contributed approximately 27 percent of the total industrial export of the country (Sakurai and Ogawa, 2006). Although Lao garment industry is considered to be young and under early stage of industrial cluster development (DTIS, 
2005), due to its capacity to pull foreign currency into country through garment products exports, it has become a prioritized sector of Lao government's strategy in economic development, poverty reduction and job creation.

As the trend of Lao garment export volume has increased, the number of subcontractor establishments have also increased. The subcontractor establishments of Lao garment industry have increased from 10 factories in year 1998 to 57 factories in year 2006 (ALGI, 2006). Its growth rate accounts for around 24 percent annually. This evidence indicates the degree of development of Lao garment industry and its subcontracting relations.

\section{THEORIES IN ANALYZING SUBCONTRACTING}

Subcontracting is usually defined as a situation where the firm offering the subcontract requests another independent enterprise to undertake the production or carry out the processing of a material, component, part or subassembly for it according to specifications or plans provided by the firm offering the subcontract (Holmes, 1986, p. 84, cited in Taymaz and Kilicaslan, 2005, p. 634). In other words, subcontracting is a specific form of outsourcing that involves intimate relations and information exchange between firms (Heshmati, 2003).

There are three different theories in analyzing subcontracting. The first theory, "dualistic approach" considers subcontracting as an unequal power relationship. Originally, this theory is based on the concept of "dualistic economy", which includes two different sets of enterprises, the large firms (multinational corporations), and the small firms (Berger and Piore, 1984). The basic understanding of this theory is that large contractors realize benefit at the expense of small contractors.

There are two main reasons why a large firm prefers to outsource production process through subcontractors. One of the main benefits is to enjoy flexibility by utilizing production capacity of subcontractors (Holmes, 1986; Watanabe, 1971). Second main benefit of subcontracting for large firms is related to cost reduction. The large firms may seek to subcontract production, particularly for unskilled labor intensive production and to take advantage of lower wages in small firms.

The second theory is "development approach" formulated mainly by development economists. It considers subcontracting as a relationship between large and small firms, but emphasizes a positive role of it: subcontracting is regarded as a tool for modernization and employment generation. Watanabe (1971) claimed that subcontracting can smooth the path of small firms to grow and make them a suitable tool for mass employment generation in developing countries that are committed to 
industrialization.

The third theory puts emphasis on networking and clustering. This "networking and clustering approach" supports networking initiatives and the development of industrial cluster (Pyke, 1992; UNCTAD, 1994). Ceglie and Dini (1999) suggest that on the account of all firms' share, small firms in the best position to help each other. They can do this through horizontal cooperation (they can collectively achieve economies of scale), vertical cooperation (they can specialize in their core activities and develop the external division of labor) and networking among enterprises, providers of business development services, and local policy makers. Rama and Calatrava (2002) posited the cluster approach as the important factor for establishing subcontracting relationships. They argued that clustering accrues significant benefits to subcontractors, particularly small or local firms. Moreover, patterns of subcontracting as a specific form of networking are associated with specific types (subcontracting relationships) of industrial clusters (Rama et al., 2003). Under these circumstances, there have some firms working as both subcontractors and contractors at the same time.

Based on three main subcontracting relation theories that have raised above, we combined first and second theories together as one approach due to their similarity in measurement variables. Therefore, in this paper we rename first and second theories as traditional approach and networking or clustering theory as modern approach.

\section{LITERATURE REVIEW AND HYPOTHESES}

There are only few studies in the field that empirically examined the determinants of subcontracting in literature. Moreover, their focuses are the determinants of subcontract-offering behavior with regards to all the firms in the concerned industry. This is different from the present study focusing only on subcontractors (excluding non-subcontractors from the sample), although the determinants of subcontracting-offering behaviors are analyzed. Here, we attempt to develop hypotheses based on the literature, but intend to obtain clearer evidences on this matter by limiting the coverage sample: determinants of subcontracting types (traditional approach-firms working as subcontractors only or modern approach-firm working as both subcontractors and contractors at the same time). 


\section{Firm Size}

Firm size is classical variable that influencing owners/managers of the firms make decision to be subcontract offering, subcontract receiving or both of them. Kimura (2002) has investigated subcontracting and the performance of small and medium firms in Japan. In his work, he not only investigated the difference in performance among groups of subcontracting firms but factors that determine subcontracting were also investigated empirically in his study. He found that firm size was negatively significant with the probability of firms working as a subcontractor. On the contrary, this variable was positive but insignificant with the probability of firms using subcontractor. He argued that small tend to work as subcontractors while large firms may use subcontractors.

In supporting the work of Kimura (2002), Taymaz and Kilicaslan (2005) found the similar results. Taymaz and Kilicaslan (2005) empirically examined the determinants of subcontracting and regional development in Turkey. In their work, they used textile and engineering industries as the case study. They found that size of firm has positive significance with subcontract-offering in both textile and engineering industries. They argue that large firms tend to subcontract a larger part of their production. They further pointed out that firm size has positive effect on both subcontract-receiving and subcontract-offering in engineering industry, although one is not statistically significant.

Based on an empirical literature, we hypothesize:

H1: Larger subcontractors are more likely to work as contractors.

\section{Wage}

In the case of wage rate variable, Taymaz and Kilicaslan (2005) confirmed that high-wage textile firms tend to subcontract a bigger part of their production. High-wage firms in engineering industry have a higher subcontract in input (subcontract-offering). Their findings seem to support the work of Watanabe (1971) who suggested that subcontractors are more specialization oriented in the engineering industry. Accordingly, we state:

H2: High-wage subcontractors are more likely to work as contractors.

\section{Female Workers}

In the case of female ratio variables, Taymaz and Kilicaslan (2005) support the work of Ypeij (1998) who observed in Peru, the share of female employees has a positive impact on subcontract offering firms in textile industry. They argue that 
female ratio has positive impact on subcontract-offering in both textile and engineering industries in Turkey. Based on aforementioned, we assume:

H3: Subcontractors that have high proportion of female workers are less likely to work as contractors.

\section{Skilled-Labor}

Skilled-labor should be one important determinant of subcontracting behavior. The evidence from literature suggests that skilled labor has negative impact on subcontract receiving model. This implies that firms employing less skilled labor tend to be subcontractors in textile industry. On the other hand, engineering firms that have a big ratio of skilled labor tend to subcontract a bigger part of their production (Taymaz and Kilicaslan, 2005). Therefore, we believe that subcontracting behavior in Lao garment industry should not be different from subcontracting behavior in textile industry in Turkey, we hypothesize:

H4: Subcontractors that have high proportion of skilled workers are more likely to work as contractors.

\section{Capital Intensity of the Production Process}

Regarding capital-labor ratio variable, Kimura (2002) posited that capital-labor ratio was negatively significant with the probability of firms working as a subcontractor. On the contrary, this variable was positive but insignificant with the probability of firms using subcontractor. He argues that labor intensive firms tend to work as subcontractors while capital intensive firms may use subcontractors. Similarly, Taymaz and Kilicaslan (2005) confirmed that capital intensive firms tend to be subcontract offering firms and labor intensive firms tend to be subcontractors in both textile and engineering sectors. Thus, we state:

H5: Subcontractors that have high capital intensity of the production process are more likely to work as contractors.

\section{Technology}

Taymaz and Kilicaslan (2005) posited that capital intensity of production process can reveal the relationship between technology and subcontracting behavior. In the case of labor intensive industry such as garment industry, machineries and their utilization are also important factor determining subcontracting behavior, but they cannot be operated well without appropriate skill and knowledge. To reflect "soft aspect" of technology, we introduce technology licensing variable. Thus, we expect: 
H6: Subcontractors that have technology licensing from parent firms abroad are more likely to work as contractors.

\section{Firm Growth}

Although, Taymaz and Kilicaslan (2005) found that growth rate of the firm has a positive impact on subcontract-offering in both textile and engineering industries. They interpreted that a rapidly growing firm is likely to subcontract out a part of the production process. Accordingly, we expect:

H7: Subcontractors that have experienced rapid growth in sales are more likely to work as contractors.

\section{Ownership}

The evidence from literature suggested that foreign-owned share is positive in the probability of using subcontractors and negative in the probability of working as subcontractors (Kimura, 2002). This indicates that affiliates of foreign firms and/or firms with a high proportion of foreign shares may actively use subcontractors while they are less likely to work as subcontractors in the case of Japan. In the case of developing country likes Lao PDR, we expect:

H8: Foreign-owned subcontractors tend to be contractors.

\section{METHODS}

\section{Sample and Data Collection}

We use data from field survey of garment firms in Vientiane Capital City (VCC), Lao PDR during August-September, 2007. Field survey has been conducted by the researchers and two lecturers of Faculty of Economics and Business Management (FEBM), National University of Laos (NUOL). Our questionnaire's design is based on the discussion points of literature. The pilot survey has been conducted through e-mail to five garment companies in VCC one month before the field survey has been done. Three questionnaires have been returned to us within two weeks. The modification of questionnaires has been done by the researchers based on the results of pilot survey.

Our original survey samples are 63 firms which include all types of Lao garment firms. Due to our main objective for this paper is to analyze the determinants of subcontracting behaviors of firms that behave as both subcontractors and contractors at the same time. Therefore, we eliminate 21 firms that do not match with our purpose. Thus our net sample is 42 garment firms located in VCC. 


\section{Measurement of Variables}

Subcontracting behaviors (SUBBEHA) is dependent variable which is defined by 1 if firms behave as both subcontract offering and receiving firms at the same time and by 0 for firms working as subcontractor only. The rest of variables are demonstrated in Table 1 as independent variables.

Table 1 Variable definitions

\begin{tabular}{ll}
\hline Variables & Definitions \\
\hline SUBBEHA & $\begin{array}{l}\text { Dummy variable equal 1 if firm working } \\
\text { as Subcontractor(s) and using } \\
\text { subcontractor(s) at the same time and } 0 \text { if } \\
\text { firm working as subcontractor(s) only. }\end{array}$ \\
\hline FS & Number of employees \\
\hline WAGE & Average wage in USD \\
\hline FRATIO & $\begin{array}{l}\text { Ratio of female workers to total } \\
\text { employees }\end{array}$ \\
\hline SKLRATIO & Ratio of skilled labors to total employees \\
\hline KLRATIO & Value of fixed assets to total employees \\
\hline TECHNO & $\begin{array}{l}\text { Dummy variable equal 1 if firm has } \\
\text { technology licensing or agreement with } \\
\text { foreign firms abroad. }\end{array}$ \\
\hline SALESGR & Average sales growth of 2004-2006 \\
\hline FOREIGNRA & Share of foreign ownership \\
\hline
\end{tabular}

\section{Analyses}

The primary analyses of the data set are based on probit regression model. Probit model has been widely used in a number of academic papers to define dichotomy dependent variables. Our econometric framework is following:

$$
\mathrm{Y}=\beta_{0}+\beta_{\mathrm{k}} \mathrm{X}_{\mathrm{n}}+\varepsilon
$$

Where $\beta_{0}$ is intercept of regression; $\beta_{k}$ is set of the coefficient of $X_{n} ; X_{n}$ is set of independent variables and $\varepsilon$ is error term. 
Therefore, our analysis model is:

\title{
SUBBEHA $=\beta_{0}+\beta_{1} \mathrm{FS}+\beta_{2} \mathrm{WAGE}+\beta_{3} \mathrm{FRATIO}+\beta_{4} \mathrm{SKLRATIO}+$ $\beta_{5}$ KLRATIO $+\beta_{6}$ TECHNO $+\beta_{7}$ SALESGR + $\beta_{8}$ FOREIGNRA $+\varepsilon$
}

\begin{abstract}
RESULTS
Table 2 illustrates descriptive statistics (Mean and Standard Deviation) and simple correlation (Pearson Correlation) between pairs of variables. It indicates that numbers of firms behaving in both subcontract offering and receiving and firms working as only subcontractors are not big different (Mean=0.47) in our sample case. The mean of FRATIO is very high (Mean=0.84) which suggests that majority worker is female. Ownership and technology variables show low mean value which indicates that subcontractors in Lao garment industry are dominated by local firms and few firms have technology licensing from companies abroad. As the correlations among pairs of variables are small, we do not worry about multicollinearity problem in our regression analysis.

We construct probit regression model in analyzing dichotomy dependent variable and the results of empirical analysis are demonstrated in Table 3. The major findings are as follows: First, the coefficients for FS, KLRATIO and FOREIGNRA are significant and positive related to subcontracting behaviors (SUBBEHA). This implies that larger subcontractors, subcontractors with capital intensity of the production process and foreign-owned subcontractors tend to behave as contractors at the same time.

Second, the coefficient for SKLRATIO is significantly and negatively related with dependent variable. The interpretation is that firms working as subcontractors only hire more skilled labor workers. Therefore, they might have benefits from their both flexibility and specialization.

Third, the coefficient for the rest of variable show interesting sign but insignificant for our regression. WAGE and SALESGR have positive coefficient. On the contrary, the coefficient for FRATIO and TECHNO are negative but insignificant. This means that wage and sales growth are not important factors in deciding whether firms will be subcontractors for other firms only or both contractors and subcontractors for other firms. In addition, high female ratio and less technology licensing from abroad exist for firms working as subcontractors only.
\end{abstract}


Table 2 Descriptive statistics

\begin{tabular}{|c|c|c|c|c|c|c|c|c|c|c|c|}
\hline Variables & Mean & SD & (1) & (2) & (3) & (4) & (5) & (6) & (7) & $(8)$ & (9) \\
\hline SUBBEHA & 0.47 & 0.5 & & & & & & & & & \\
\hline FS & 156.19 & 229.14 & $0.45 * *$ & & & & & & & & \\
\hline $\mathrm{WAGE}^{\mathrm{a}}$ & 0.47 & 0.08 & $0.45 * *$ & $0.31 *$ & & & & & & & \\
\hline FRATIO & 0.84 & 0.08 & -0.17 & -0.19 & -0.16 & & & & & & \\
\hline SKLRATIO & 0.08 & 0.04 & -0.2 & -0.08 & 0.03 & 0.01 & & & & & \\
\hline KLRATIO $^{b}$ & $1,679.01$ & $3,727.46$ & 0.24 & -0.11 & 0.08 & 0.19 & -0.01 & & & & \\
\hline TECHNO & 0.21 & 0.41 & $0.31 *$ & $0.42 * *$ & 0.33 & -0.12 & -0.17 & -0.03 & & & \\
\hline SALESGR & 33.07 & 42.82 & 0.06 & 0.11 & -0.07 & 0.01 & 0.07 & 0.18 & 0.06 & & \\
\hline FOREIGNRA & 0.26 & 0.43 & $0.47 * *$ & $0.47 * *$ & $0.35^{*}$ & -0.25 & -0.04 & -0.06 & $0.42 * *$ & 0.03 & - \\
\hline
\end{tabular}

Table 3 Empirical results

\begin{tabular}{lccc}
\hline \multirow{2}{*}{ Explanatory variables } & \multicolumn{3}{c}{ SUBBEHA } \\
\cline { 2 - 4 } & Coefficient & t-statistics & Prob \\
\hline FS & 0.004 & 2.218 & 0.026 \\
\hline WAGE & 4.613 & 1.625 & 0.184 \\
\hline FRATIO & -2.520 & -1.414 & 0.157 \\
\hline SKLRATIO & -12.987 & -2.202 & 0.035 \\
\hline KLRATIO & 0.001 & 3.909 & 0.000 \\
\hline TECHNO & -1.217 & -1.281 & 0.199 \\
\hline SALESGR & 0.004 & 0.843 & 0.398 \\
\hline FOREIGNRA & 1.194 & 1.524 & 0.027 \\
\hline Log likelihood & -16.092 & & \\
\hline SOL
\end{tabular}

Source: Authors, Eviews analysis' results

\section{DISCUSSION}

Our main aim in this paper is to identify the determinants of subcontracting behaviors of firms that are engaged with both subcontractors and contractors at the same time in Lao garment industry. As have been illustrated in the previous section, we come up with some interesting results. Firstly, our results confirm that there is positive relationship between firm size, capital intensive and foreign ownership variables and subcontracting behaviors. Therefore, hypothesis $\mathrm{H} 1, \mathrm{H} 5$ and $\mathrm{H} 8$ are supported. The interpretation of these results is that larger subcontractors, subcontractors with capital intensity of the production process and foreign-owned subcontractors play the role in being contractors at the same time. Considering 
structure of industry in Lao PDR as well as in other countries, most of the large subcontractors are foreign-owned firms which have high capital-labor ratio. Obviously, due to this phenomenon these firms should have no different behavior.

As far as subcontracting is concerned, we can note that with regards to subcontracting behaviors of garment firms in Lao PDR, larger firms not only offer subcontract to smaller firms (unequal relationship), but also they offer subcontract to firms in same size (equal relationship). This suggests that subcontracting in Lao garment industry tends to follow modern approach (networking/clustering approach). Based on the information from our interview of owners/managers they revealed that they are maintaining the relationship with other firms as well as possible. Even though some occasions their orders from customers are not high, but to maintain aforementioned relationship they need to offer some subcontract to their subcontractors (in some cases offer subcontract to partners).

To support our argument, empirical results suggest that wage and female ratio are insignificant although the signs of both variables are consistent with our hypothesis. Therefore, hypothesis $\mathrm{H} 2$ and $\mathrm{H} 3$ are not statistically supported. Consequently, we need to argue that traditional subcontracting relation that has been simplified as the relationship between high wage firms employing male workers and low wage firms employing female workers is not important factor in explaining subcontracting behaviors of Lao garment industry. Instead, we need to state that among subcontracting firms network is an important way for the firms to overcome the rapid change of market at both domestic and international levels.

Secondly, there is negative relationship between skilled labor ratio and subcontracting behaviors. The sign of this variable is inconsistent with our hypothesis but it is statistically significant. Thus, hypothesis H4 is not supported. However, this result seems to be interesting and unique in the case of Lao garment industry. This means that subcontractors in Lao garment industry are hiring high ratio of skilled labors compared with firms behaving as both contractors and subcontractors at the same time. Therefore, they should have advantage in terms of flexibility and specialization from their division of labor.

Lastly, Hypothesis H6 that hypothesized subcontractors having technology licensing will be also contractors at the same time is not supported. The reason behind this appearance is due to our sample is firm that regards to subcontract receiving activities. However, if we include firms that offer subcontracting only into the model, the results might be different. In addition, we lack of evidence to support the mentioned that firms offer subcontract to other firms due to rapid growth of their 
sales. According to the results, hypothesis $\mathrm{H} 7$ is also not supported. In our sample, the growth rate of sales is not big different among two groups of firms. This might be one reason why sales growth is not important factor in explaining subcontracting behaviors of Lao garment industry.

\section{CONCLUSION}

This paper has tried to answer research question: what are the determinants of subcontracting behavior of Lao garment industry? Based on the analysis of 42 subcontractors located in VCC, Lao PDR, we found that firm size, capital intensity of the production process and foreign ownership and skilled labor are important factors that determine subcontract-offering behavior. In contrast, we observed that wage, female workers, technology and sales growth are not important determinants in explaining subcontract-offering behavior in our case study.

We conclude that larger subcontractors, subcontractors that have high capital intensity of the production process and foreign-owned subcontractors are more likely to work as contractors at the same time. On the other hand, higher skilled labor firms tend to be subcontractors in the case of Lao garment industry. According to the findings, we argue that traditional approach that explains the relationship between high wage firms employing male workers and low wage firms employing female workers is not dominant behavior in Lao garment industry. Instead, modern approach (networking or clustering approach) that explains the inter-firm cooperation is dominant in our case study. Lao garment firms that subcontract out of their production process are not to gain the advantage from lower labor cost from others. In fact, to maintain the relationship among contractors and subcontractors is important behavior.

Our contribution to the academic literature is twofold. Firstly, to the best of our knowledge, this is the first empirical work investigating only subcontractor' behaviors. Secondly, we show how the different determinants of subcontracting in the case of subcontractors (our case study) and subcontracting as a whole (literature).

Based on our empirical results, we recommend to policy makers as follows: our study sheds light on the initiative of cluster development in Lao garment industry. The development of subcontracting relations is one form of industrial cluster development, specifically if garment firms behave as both contractors and subcontractors. This type of relationship promotes networking or clustering faster than others. Therefore, it should be the way for long-term development of industrial cluster. As result, it can enhance not only firm performance but also regional as well as national economic development. 


\section{REFERENCES}

Andrabe, T., Ghatak, M., and Khwaja, A. I. (2006) Subcontractors for tractors: Theory and evidence on flexible specialization, supplier selection, and contracting. Journal of Development Economics, 79(2), 273-302.

Association of Lao Garment Industry. (2006). Garment Statistics 2005-2006. Vientiane: ALGI.

Berger, S., and Piore, M. J. (1984). Dualism and discontinuity in Industrial Societies. Cambridge: Cambridge University Press.

Bounthavy, S., Keomanivone, P., Vena, N., Vilayvanh, P., Vilaysack, S. \& Phetsamone, S. (2007). Addressing the impact of the phasing out of textiles and clothing quotas in Lao PDR. Vientiane: National Statistics Centre.

Boutsivongsak, O., Pisith, C. and Keith, S. (2002). A Comprehensive Framework to Forster Economic Initiative in LAO PDR: The Textile and Garment Industry in the Lao PDR. United Nations Industrial Development Organization: Vientiane.

Burki, A. A. and Terrell, D. (1998). Measuring production efficiency of small firms in Pakistan. World Development, 26(1), 155-169.

Ceglie, G. and Dini, M. (1999). SME cluster and networking development in developing countries: The experience of UNIDO. Working Paper No. 2. Private Sector Development Branch, Vienna: UNIDO.

DTIS (2005). Laos: Diagnostics Trading Integration Study Concept Paper. Vientiane: World Bank.

Hayashi, M. (2002). The role of subcontracting in SME development in Indonesia: Micro-level evidence from metalworking and machinery industry. Journal of Asian Economics, 13, 1-26.

Heshmati, A. (2003). Productivity growth, efficiency and outsourcing in manufacturing and service industries. Journal of Economic Survey, 17, 79-112.

Holmes, J. (1986). The organization and locational structure of production subcontracting. In A. J. Scott, \& M. Storper (Eds.), Production, work, and territory: The geographical anatomy of industrial capitalism (pp. 80-106). Allen \& Unwin, Boston: MA.

Kimura, F. (2002). Subcontracting and the performance of small and medium firms in Japan. Small Business Economics, 18(2), 163-175.

Labrianidis, L. (1995). Subcontracting in the Greek garment industry and the opening of the Balkan markets. Cyprus Journal of Economics, 9(1), 29-45.

Pyke, F. (1992). Industrial Development Through Small-firm Co-operation. ILO: Geneva. 
Rama, R., and Calatrava, A. (2002). The advantages of clustering: the case of Spanish electronics subcontractors through spatial clustering. International Journal of Technology Management, 24(8), 764-791.

Rama, R., Ferguson, D. and Melero, A. (2003). Subcontracting networks in industrial districts: the electronics industries of Madrid. Regional Studies, 37(1), 71-88.

Rosés, J. R. (2005). Subcontracting and vertical integration in the Spanish cotton industry. Working Paper 05-13, Economic History and Institutions Dept. Universidad Carlos III de Madrid.

Sakurai, A. and Ogawa, K. (2006). Assessment of current garment industry in the Lao PDR: Based on a field survey in Vientiane City. Journal of International Cooperation Studies, 14(1), 55-75.

Spiegel, Y. (1993). Horizontal subcontracting. RAND Journal of Economics, 24(4), 571-590.

Takahashi, Y. and Xayphone, K. (2008). Impact of Inter-firm Cooperation on Performance: The Case of Garment Industry Cluster in Vientiane Capital City, Lao PDR. In The $4^{\text {th }}$ Proceeding of International Symposium of Asian Regional Policy (pp. 133-135). Takasaki City: Takasaki City University of Economic.

Taymaz, E. and Kiliçaslan, Y. (2005). Determinants of subcontracting and regional development: An empirical study on Turkish textile and engineering industries. Regional Studies, 39(5), 633-645.

Unni, J., Bali, N. and Vyas, J. (1999). Subcontracted women workers in the global economy: Case of garment industry in India. Ahmedabad, India: Self Employed Women's Association (SEWA).

UNIDO (2003). International Subcontracting Versus Delocalisation? Austria: Vienna.

UNCTAD. (1994). Technological Dynamism in Industrial Districts: An Alternative Approach to Industrialization in Developing Countries. New York: United Nations.

Watanabe, S. (1971). Subcontracting, industrialization and employment creation. International Labour Review, 104, 51-76.

Wattanapruttipaisan, T. (2002). SME subcontracting as bridgehead to competitiveness: An assessment of supply-side capability and demand-side requirement. Asia-Pacific Development Journal, 9(1), 65-87.

Ypeij, A. (1998). Transferring risks, microproduction, and subcontracting in the footwear and garment industries of Lima, Peru. Latin American Perspectives, 25(2), 84-105. 